УДК 347

DOI https:/ / doi.org/10.32837/yuv.v0i1.1562

\author{
Ю. Кривенко, \\ кандидат юридичних наук, доцент, \\ доцент кафедри цивільного права \\ Національного університету «Одеська юридична академія» \\ Н. Адаховська, \\ кандидат юридичних наук, доцент, \\ доцент кафедри цивільного права \\ Національного університету «Одеська юридична академія»
}

\title{
ПРАВО ВЛАСНОСТІ РЕЛІГІЙНИХ ОРГАНІЗАЦІЙ: ТЕОРЕТИЧНІ ТА ПРАКТИЧНІ АСПЕКТИ
}

У механізмі здійснення права на віросповідання, яке належить до основних прав і свобод людини, найважливішою ланкою $€$ релігійна організація, що виступає як найбільш сталий ідеологічний і політичний інститут людства, займає особливе місце в суспільстві та впливає на державну політику. Релігійні організації мають чималу власність, доходи, беруть участь у цивільному обороті та є суб'єктами права власності.

Держава в різні історичні епохи по-різному сприймала співвідношення правових норм i церковних канонів у вирішенні цивільно-правових питань, зокрема щодо права власності релігійних організацій.

Право церкви на володіння майном канонічно закріплене, однак цього недостатньо. Як правильно зазначав А.С. Павлов: «Щоб природне право церкви на придбання майна у власність вливалося у звичайні форми приватного або цивільного права, для цього необхідно, щоб держава, у сфері діяльності якої знаходяться всі матеріальні блага, визнала церкву суб'єктом прав, тобто юридичною особою. В іншому разі церква може володіти майном тільки фактично» [1].

Зокрема, «в римському праві була поширеною теорія, що майно, яке призначене виключно для церковних потреб, належить Богові; прихиль- ники іншої думки стверджували, що майно церкви - це власність жебраків. У Західній Європі була висунута теорія загальноцерковної власності, котра полягала у визнанні Папи суб'єктом власності на церковне майно, хоча за деяких причин прямо це не проголошувалося. Тривалий час під впливом антихристиянської ідеології природного права складалася публіцистична теорія, яка право власності церковного майна переносила на державу» [2, c. $128-131]$.

Необхідно зазначити, що релігійна організація нині класифікована як самостійна організаційно-правова форма, відмінна від інших форм юридичних осіб і насамперед від громадських організацій, враховуючи специфічні цілі, які стоять перед релігійними організаціями.

Будь-яка ідеологічна надбудова не може існувати без своєї матеріальної основи, вираженої в інституті власності. Історія становлення релігійних організацій підтверджує цю закономірність. Тому актуальним є дослідження розвитку i трансформації інституту власності релігійних організацій з урахуванням практичних і теоретичних проблем сьогодення, враховуючи, те, що зараз держава активно долучається до релігійних справ.

Питання щодо розвитку відносин права власності релігійних організацій 
зазнали значних змін. Після падіння монархії в Російській імперії, до складу якої входила й Україна, релігійні організації виявилися фактично позбавленими будь-яких прав на майно, але з часом їхне становище змінилося на краще, що було пов'язано з припиненням відкритих репресій, а потім і коригуванням політики соціального відчуження від релігії.

До питання права власності релігійних організацій зверталися багато науковців, таких як В.Н. Мироненко, В.Ф. Піддубна, О.В. Рибалко та ін. Але ці питання і досі $€$ дискусійними та потребують вирішення.

Метою статті $€$ дослідження проблем теорії та практики права власності релігійних організацій.

На початку дослідження ми сформулювали такі гіпотези, які були підтверджені у процесі роботи: релігійні організації є самостійними суб'єктами цивільного права та суб'єктами права власності; релігійні організації володіють майном на праві власності; актуальними є питання щодо права власності на землю та культові споруди.

Вітчизняний законодавець у ст. 35 Конституції України зазначив, що кожен має право на свободу світогляду і віросповідання. Це право включає свободу сповідувати будь-яку релігію або не сповідувати ніякої, безперешкодно відправляти одноособово чи колективно релігійні культи та ритуальні обряди, вести релігійну діяльність [3].

Із 20 січня 1918 р. ніякі церковні та релігійні громади не мали права володіти власністю і не мали прав юридичних осіб. Все майно церковних i релігійних товариств у 1918 р. було націоналізовано.

Питання щодо того, хто є власником церковного майна, в різні періоди вирішувалося по-різному - від оголошення всього майна власністю Бога або жебраків до визнання власником громади як корпорації [4].

Ми будемо дотримуватися сучасного, заснованого на законодавстві підходу, згідно з яким за релігійною організацією визнається цивільна правоздатність. Набуття релігійною організацією статусу юридичної особи означає закріплення за нею відокремленого майна [5, с. 67]. Те, що релігійні організаціі можуть мати у власності будівлі, земельні ділянки та інші об'єкти, прямо визначено в законодавстві. Таким чином, релігійні організації визнаються суб'єктами права власності на законодавчому рівні.

Відповідно до норм цивільного права власник має право розпоряджатися належним йому майном на свій розсуд iз невеликими обмеженнями (що стосуються суспільної користі та безпеки, а також прав та інтересів інших осіб і деякими іншими), то правова охорона майна, присвяченого Богу за допомогою передачі його релігійним організаціям, має свою специфіку і здійснюється 3 урахуванням більш суворих обмежень, ніж щодо іншого майна. Особливості правового регулювання майна релігійних організацій пояснюються тим, що воно служить не приватному, а спільному інтересу, і тому піддається обмеженню, ніж виключно приватний інтерес (хоча формально, 3 погляду цивільного права, релігійні установи мають статус приватної (юридичної) особи).

Історія свідчить про важливість визнання цієї специфіки світським законодавством. Інакше фактичне розпорядження майном релігійних організацій недобросовісними власниками або користувачами може суперечити церковним канонам, будучи правомірним із погляду цивільного права. Чим більше зміцнюється майновий стан Церкви, тим більша кількість об'єктів культурної спадщини національного та міжнародного значення вона фактично може контролювати.

Згідно зі ст. 316 ЦК України правом власності є право особи на річ (майно), яке вона здійснює відповідно до закону за своєю волею незалежно від волі інших осіб [6].

Положенням ст. 18 Закону Украіни «Про свободу совісті та релігійні 
організації» визначено, що релігійні організації володіють, користуються і розпоряджаються майном, яке належить їм на праві власності [7]. Релігійні організації можуть бути обмежені у здійсненні права власності лише у випадках і в порядку, передбачених законом. У власності релігійних організацій можуть бути будівлі, предмети культу, об'єкти виробничого, соціального і добродійного призначення, транспорт, кошти та інше майно, необхідне для забезпечення їхньої діяльності.

Таким чином, видається доцільним визначити поняття «право власності релігійних організацій». Так, під правом власності релігійних організацій слід розуміти право добровільного, організаційно оформленого, постійно діючого об'єднання віруючих, що базується на єдності віросповідання, культовій, обрядовій практиці, створеного ними для задоволення своїх релігійних і пов'язаних із ними потреб, інтересів і проведення необхідної для нього відповідної діяльності на будівлі, предмети культу, об'єкти виробничого, соціального і добродійного призначення, транспорт, кошти та інше майно, необхідне для забезпечення діяльності релігійної організації, яке вона здійснює відповідно до закону, маючи визначені ним обмеження.

Також, розкриваючи сутність права власності релігійних організацій, варто відзначити, що воно, як і будь-яке інше право, має свій зміст.

Згідно зі ст. 317 ЦК України власникові належать права володіння, користування та розпоряджання своїм майном [8] Базуючись на основах цивільного права, у ст. 18 Закону України «Про свободу совісті та релігійні організації зазначається, що релігійні організації володіють, користуються i розпоряджаються майном, яке належить їм на праві власності [9].

Володіння релігійної організації слід визначити як закріплену нормами права можливість релігійних організацій, що полягає у реальному матеріальному зв'язку релігійної організації з будівлями, предметами культу, об’єктами виробничого, соціального і добродійного призначення, транспортом, коштами та іншим майном, необхідним для забезпечення діяльності.

3 огляду на вищевказане під правом користування релігійної організації слід визначити закріплену нормами права можливість добування корисних властивостей будівель, предметів культу, об'єктів виробничого, соціального і добродійного призначення, транспорту, коштів та іншого майна для задоволення потреб релігійної організації.

Досліджуючи право розпорядження, слід погодитися з В. Мироненко щодо того, що «його ознакою є усвідомлений вольовий акт. Без волі власника здійснення права розпоряджання $є$ неможливим, тоді як право володіння та право користування можуть і не мати вольового компонента.

Право розпоряджання охоплює значне коло дій, які може вчиняти власник, зокрема:

- дії власника, спрямовані на передачу права власності іншій конкретній особі. До цієї групи належать договори купівлі-продажу, поставки, міни, дарування та інші, тобто право на відчуження речі;

- дії власника, спрямовані на передачу іншій особі частини своїх прав. Сюди слід віднести договір найму;

- право власника укладати правочини на встановлення обтяжень свого права власності. Це встановлення сервітуту, застави;

- діі власника, спрямовані на знищення майна, на припинення фізичного існування речі не у зв'язку з їі споживанням, тобто право фізично знищити річ (спалити, поламати, позбавивши їі будь-якої цінності). У цьому разі право власності на річ припиняється;

- відмова власника від права власності на річ» [10, с. 28-33].

Досліджуючи сутність права власності релігійних організацій, слід вказати, що, як зазначається у ст. 18 Закону України «Про свободу совісті та релігійні організації, релігійні організа- 
ції мають право власності на майно, придбане або створене ними за рахунок власних коштів, пожертвуване громадянами, організаціями або передане державою, а також придбане на інших підставах, передбачених законом. У власності релігійних організацій може бути також майно, що знаходиться за межами України.

Релігійні організації мають право звертатися за добровільними фінансовими та іншими пожертвуваннями й одержувати їх. Фінансові та майнові пожертвування, як і інші доходи релігійних організацій, не оподатковуються. Релігійні організації не мають права проводити примусове обкладання віруючих різноманітними зборами.

Також варто проаналізувати питання щодо визначення форми власності релігійних організацій.

На думку А.А. Кирилова, власність релігійних організацій має як приватний, так і публічний характер. На його думку, спостерігається поділ власності згідно із суб'єктами, яким вона належить. Власність фізичних і юридичних осіб є приватною, а майно, що перебуває на балансі державних установ, - публічним. Але він вказує на наявність такого виду власності, який містить у собі ознаки різних видів власності [11, с. 52-57].

В.А. Рибаков вказує: «Враховуючи канонічні норми, можна стверджувати, що церковна власність не належить ні до приватної, ні до комунальної, ні до державної власності. Вона є особливою самостійною формою власності». [12, c. 121-122].

К.Я. Ананьєва та М.В. Хлистов також стверджують, що «власність релігійних організацій «належить до інших форм власності, становлячи особливу форму власності, оскільки має особливий характер привласнення майна (його усуспільнення), особливості суб'єктного й об'єктного складу, а також змісту правовідносин власності» $[13$, с. $15-17]$.

Попри наукові дослідження, в Украіні складається досить неоднозначна практика, яку яскраво можна показати на прикладі м. Одеса. Зокрема, за дослідженнями видання «Думская», «в Одесі, статус пам'ятника архітектури отримали 16 одеських храмів. Один із них - Грецька церква Святої Трійці початку XIX ст. - пам'ятник національний. Цей об'єкт знаходиться в комунальній власності територіальної громади міста. Московському патріархату він переданий у безкоштовне користування.

Дев'ять споруд, що мають історичну та культурну цінність, належать безпосередньо єпархіі: Воскресенська на Бернардацці (Червоних Зір); Дмитрівська на Другому Християнському кладовищі; Андріївське подвір'я Афонського монастиря на розі Пантелеймонівської та Лейтенанта Шмідта; Пантелеймонівське подвір'я Афонського монастиря на Пантелеймонівській, 66; Успенський собор на Преображенській; Іллінська церква Афонського подвір'я на Пушкінській; Спасо-Преображенський собор; Михайлівський жіночий монастир на Успенській; церква Адріана і Наталії на Французькому бульварі.

Церква Григорія Богослова на Старопортофранківській і комплекс споруд Свято-Успенського монастиря на 16-й станції Великого Фонтану оформлені на «єпархіальні» громади. Свято-Троїцька церква на Неждановій (Крива Балка) є власністю «правильної» громади, заснованої 12 фізичними особами. Церква Скорбященського 1868 р. на розі Базарної та Бєлінського (Леонтовича) належить фізособі - відомому бізнесмену Борису Кауфману. Два храми - церква Святого великомученика і цілителя Пантелеймона 1888 р. побудови на курорті Куяльник і церква Різдва 1848 р. на Слобідці - відсутні в реєстрі нерухомості: вони «нічиї» [14]. Крім того, ще варто згадати, про можливість виникнення міжконфесійних суперечок і конфліктів, під час надходження заявок щодо культової будівлі від релігійних організацій різних конфесій, що мають рівні права на цю будівлю 


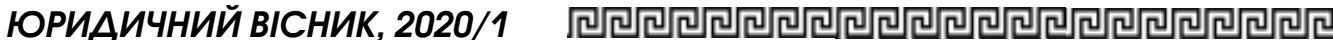

у зв'язку з тим, що конфесійна належність культової будівлі протягом їі існування могла змінюватися.

Також не варто нехтувати проблемними питаннями щодо культових споруд, які мають культурну цінність і є музеями, на кшталт Києво-Печерської Лаври чи Володимирського собору, але це питання потребує окремо дослідження.

Отже, у підсумку слід визначити, що починаючи 31918 р. законодавство 3 питань права власності релігійних організацій зазнало значних змін і розроблялося без урахування церковних канонів. Відповідно до чинного законодавства церква та релігійні організації відділені від держави. Релігійні норми впливають на життя насамперед віруючої людини, однак не варто применшувати їх значення для суспільства загалом. Розглядаючи питання права власності релігійних організацій на сучасному етапі, необхідно враховувати всі складники правової системи суспільства, в т. ч. і міжнародні норми, які входять до іiі складу, а також канонічні норми, що є складовою частиною статутів релігійних організацій.

Законом закріплено, що релігійні організації володіють, користуються і розпоряджаються майном, яке належить їм на праві власності, однак існують певні особливості здійснення права власності релігійними організаціями, зумовлені їхньою правовою природою.

Власність релігійних організацій не належить ні до приватної, ні до колективної власності. Вона є іншою, особливою формою власності, оскільки має особливий характер привласнення майна (його усуспільнення), особливості суб'єктного й об'єктного складу, а також змісту правовідносин власності.

У статті аналізуються як теоретичні, так $і$ практичні питання права власності релігійних організацій, із коротким використанням історичних прикладів. Спори та дискусї щодо права власності релігійних організацій не тільки не вщухають, але навпаки, набирають нової сили, втягуючи в круговорот суперечностей вчених $i$ практиків, враховуючи те, що існуе багато так званих «важких» питань, які необхідно вирішувати, а саме, питання, що стосуються права власності на землю та культові споруди.

Релігійні організаиіі мають чималу власність, доходи, беруть участь у изивільному обороті $i$ є суб'єктами права власності.

Відповідно до норм иивільного законодавства релігійні організаціі володіють, користуються $i$ розпоряджаються майном, яке належить їм на праві власності.

На праві власності їм належить майно, придбане або створене ними за рахунок власних коштів, пожертвуване громадянами, організаціями або передане державою, а також придбане на інших підставах, передбачених законом. У власності релігійних організацій може бути також майно, що знаходиться за межами України.

Під правом власності релігійних організацій сліо розуміти право добровільного, організаиійно оформленого, постійно діючого об'єднання віруючих, яке базується на єдності віросповідання, культовій, обрядовій практиці, створеного ними для задоволення своїх релісійних і пов'язаних із ними потреб, інтересів $i$ проведення необхідної для нього відповідної діяльності на будівлі, предмети культу, об'єкти виробничого, соціального $і$ добродійного призначення, mранспорт, кошти та інше майно, необхідне для забезпечення діяльності релігійної організації, яке вона здійснюе відповідно до закону, маючи визначені ним обмеження.

Однак у нашому дослідженні питання щодо предметів культу, щцо належать на праві власності релігійним організаціям, не розглядалося.

На основі аналізу різних думок, висловлених у науковій літературі, а також положень цивільного законодавства робиться висновок про 
mе, що власність релігійних організацій не належить ні до приватної, ні до колективної власності. Вона належить до інших форм власності з урахуванням особливого характеру привласнення майна, специфіки суб'єктного й об'єктного складу, а також змісту правовідносин власності. Деякі положення мають дискусійний характер $i$ можуть слугувати базою для подальших наукових досліджень.

Ключові слова: право власності, приватна власність, релігійні організації, нерухомість.

Adakhovska N., Kryvenko I. The right of ownership of religious organizations: theoretical and practical aspects

The article analyzes both theoretical and practical issues of property rights of religious organizations, with a brief use of historical examples. Disputes and debates over the ownership of religious organizations not only do not subside, but on the contrary, gain new strength, drawing into the cycle of contradictions between scholars and practitioners, given that there are many so-called "difficult" issues to be addressed, namely relating to the ownership of land and religious buildings.

Religious organizations have considerable property, income, participate in civil turnover and are subjects of property rights.

In accordance with the norms of civil law, religious organizations own, use and dispose of property that belongs to them on the right of ownership.

They own property, acquired or created by them at the expense of their own funds, donated by citizens, organizations or handed over by the state, as well as acquired by the state. Religious organizations may also own property located outside Ukraine.

Under the ownership right of religious organizations should be understood as the right of a voluntary, organizationally formed, permanent association of believers, based on the unity of religion, cult, worship and created by them for realization of their religious and related needs, interests and implementation for him appropriate activities on buildings, objects of worship, objects of industrial, social and charitable purpose, transport, funds and other property necessary to ensure the activities of a religious organization, which it carries out in accordance with the law, while having certain restrictions.

However, in this study, the issue of religious objects owned by religious organizations was not examined.

Based on the analysis of various points of view expressed in the scientific literature, as well as the provisions of civil law, it is concluded that the property of religious organizations does not belong to either private or collective property. It refers to other forms of ownership, taking into account the special nature of property appropriation, the specifics of the subject and object composition, as well as the content of property relations. Some provisions are debatable and can serve as a basis for further research.

Key words: property rights, private property, religious organizations, real estate.

\section{Література}

1. Павлов А.С. Из лекиий. Имущественное право Церкви. Богословский вестник. 1901. T. 3. № 10.

2. Кривенко Ю.В. Майнові права релігійних організацій. Актуальні проблеми держави і права. 2008. № 38. С. 128-131.

3. Конституція України від 28 червня 1996 р. Відомості Верховної Ради України. 1996. № 30. Cm. 141.

4. Цыпин В.А., прот. Церковное право : курс лекции. Москва: Кругльй стол по религиозному образованию в Русской православной иеркви.

5. Кривенко Ю.В.Цивільно-правовий статус релігійних організацій в Украіні : дис. ... канд. юрид. наук: 12.00.03 / кер. роботи Є.О. Харитонов ; Нац. ун.-m «Одеська юридична академія». Одеса, 2007. $194 \mathrm{c}$. 


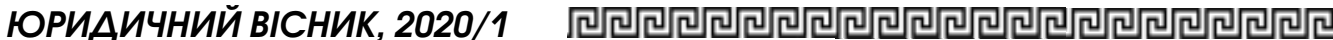

6. Цивільний кодекс України від 16 січня 2003 р. № 435-IV. Відомості Верховної Ради України. 2003. № 40-44. Ст. 356 .

7. Про свободу совісті та релігійні організації : Закон України від 23 квітня 1991 р. № 987-ХII. Відомості Верховноі Ради України. 1991. № 25. Ст. 283.

8. Цивільний кодекс України від 16 січня 2003 р. № 435-IV. Відомості Верховної Ради України. 2003. № 40-44. Ст. 356.

9. Про свободу совісті та релігійні організащії : Закон України від 23 квітня 1991 р. № 987-ХII. Відомості Верховної Ради України. 1991. № 25. Cm. 283.

10. Мироненко В. Права володіння, користування $і$ розпорядження власністю за иивільним правом. Підприємниитво, господарство і право. 2019. № 1. С. 28-33.
11. Кириллов А.А. Собственность религиозных организаиий. Законодательство и экономика. 2012. № 1. С. 52-57.

12. Мечетина T.A., Рььбаков В.А., Рыбаков В.В. Учение о формах собственности: иивилистический аспект : монография. Рязань : Издательство "Кониеепияя, 2016. C. 121-122.

13. Ананьева К.Я., Хльстов М.В. $K$ вопросу о форме собственности религиозных организаций. Юридическая наука. 2017. № 2. C. 15-17.

14. Общее, епархиальное и ничье: кому принадлежат храмы Московского nатриархата в Одесской области (инфографика). URL: https://dumskaya.net/ news / obshchee-eparhialnoe-i-niche-komuprinadlezhat-h_-094622/. 